\title{
Meningkatkan Sikap Bertanggung Jawab Melalui Penerapan Model Hellison dalam Pembelajaran Penjas
}

\section{Improving Responsibility through The Application of The Hellison Model in Penjas Learning}

\author{
Deswita Supriyatni \\ STKIP Pasundan, Cimahi, Jawa Barat, Indonesia \\ deswita291284@gmail.com
}

\begin{abstract}
Abstrak
Penelitian ini bertujuan untuk melihat peningkatan sikap tanggung jawab siswa di SMK TIK Yadika Cicalengka melalui penerapan model hellison dalam pembelajaran penjas. Metode penelitian yang digunakan adalah metode eksperimen dengan desain one grup pretest-posttest design. Sampel penelitian ini adalah siswa kelas XI Akuntansi yang diambil secara cluster random sampling pada siswa kelas XI di SMK TIK Yadika Cicalengka. Penelitian dilakukan 1 kali pertemuan setiap minggunya selama 8 minggu. Instrumen yang digunakan adalah angket tanggung jawab. Data yang diperoleh diolah menggunakan SPSS 24 melalui Uji-t Paired Samples. Hasil penelitian mengungkapkan bahwa nilai Sig. (2-tailed) sebesar 0,000<0,05, karena nilai Sig. (2-tailed) sebesar 0,000 lebih kecil dari 0,05 maka dapat disimpulkan bahwa penerapan model hellison dalam pembelajaran penjas dapat meningkatkan sikap betanggung jawab siswa. Berdasarkan hasil tersebut dapat dikatakan bahwa penerapan model hellison dalam pembelajaran penjas dapat berpengaruh secara signifikan terhadap peningkatan sikap tanggung jawab siswa di SMK TIK Yadika Cicalengka.
\end{abstract}

Kata kunci : model hellison dan sikap tanggung jawab.

\begin{abstract}
This study aims to see an increase in the attitude of student responsibility in ICT Vocational School Yadika Cicalengka through the application of the Hellison model in penjas learning. The research method used was the experimental method with the design of one group pretest-posttest design. The sample of this study was class XI Accounting students taken by cluster random sampling on class XI students at ICT Vocational School Yadika Cicalengka. The study was conducted once a week for 8 weeks. The instrument used is a questionnaire of responsibility. The data obtained is processed using
\end{abstract}


SPSS 24 through the Paired Samples t-Test. The results revealed that the Sig. (2-tailed) of 0,000 $<0,05$, because of the Sig. (2-tailed) of 0,000 less than 0.05, it can be concluded that the application of the hellison model in penjas learning can improve students' responsible attitudes. Based on these results it can be said that the application of the hellison model in penjas learning can significantly influence the increasing attitudes of student responsibility in ICT Vocational School Yadika Cicalengka.

Keywords: hellison model and attitude of responsibility

\section{PENDAHULUAN}

Manusia hidup memerlukan bekal pendidikan untuk mempertahankan dan melangsungkan hidupnya. Dari mulai manusia lahir kedunia setiap manusia akan tumbuh dan berkembang. Salah satu bekal hidup manusia adalah pengetahuan. Pengetahuan didapatkan dari proses pendidikan. Pendidikan yang dimaksud bersifat formal dan non formal. Pendidikan formal berasal dari dunia persekolahan. Sedangkan pendidikan non formal dimulai dari keluarga. Kemudian diperluas dengan pendidikan di lingkungan luar rumah. Pendidikan adalah kumpulan dari semua proses yang memungkinkan seseorang mampu mengembangkan seluruh kemampuan (potensi) yang dimilikinya, sikap-sikap dan bentuk-bentuk perilaku yang bernilai positif di masyarakat tempat individu yang bersangkutan berada (Sukardjo 2009)

Perkembangan sikap dan perilaku anak dipengaruhi oleh pendidikan di tiga lingkungan tersebut, di tempat anak-anak melakukan sosialisasi dan interaksi. Namun kebanyakan orang menyalahkan semua perilaku anak baik yang positif maupun negatif merupakan pengaruh dari pendidikan di sekolah. Guru sebagai pendidik sekaligus pengganti orang tua di sekolah kerap kali disalahkan sebagai penyebab terjadinya perilaku-perilaku negatif siswa. Padahal kenyataannya semua penyimpangan yang dilakukan siswa bukan berarti karena salahnya cara mendidik seorang guru di sekolah ataupun kurangnya pengawasan serta penanganan guru untuk siswa yang menyimpang, tetapi semua yang dilakukannya merupakan akibat dari kurangnya rasa bertanggung jawab.

Salah satu kasus yang sedang marak akhir-akhir ini adalah tawuran antar pelajar. Tawuran antar pelajar sepertinya telah menjadi hal yang lumrah terjadi di lingkungan persekolahan. Bulan November tahun 2016 saja telah terjadi 4 kasus tawuran antar pelajar SMA dan SMK. Belum lagi bulan-bulan sebelumya. Bahkan tawuran antar pelajar menyebabkan banyak korban terluka hingga meregang nyawa. Seperti kasus tawuran yang terjadi di Kabupaten Tangerang, saat tawuran terjadi tiga siswa sengaja mengeroyok seorang siswa dengan melakukan penusukan di punggungnya hingga mengalami luka serius dan akhirnya tewas. Selain tawuran antar SMA dan SMK, dunia 
pendidikan juga dikagetkan oleh sejumlah siswa Sekolah Dasar (SD) di Pakunden kota Semarang yang terlibat tawuran dengan menggunakan senjata tajam. Tingginya angka tawuran dalam dunia persekolahan, merupakan efek dari pengendalian emosi yang belum stabil.

Kita sebagai orang tua seharusnya mulai memperbaiki serta membenahi semua yang salah, seperti perilaku menyimpang anak karena kurangnya rasa tanggung jawab di dalam diri sendiri. Rasa tanggung jawab terhadap diri sendiri harus ditanamkan di dalam diri, karena sikap bertanggung jawab yang telah ditanamkan akan membuat seseorang lebih bertanggung jawab atas tindakannya. Setelah itu, anak akan memiliki sikap tanggung jawab pula terhadap orang lain. Seperti yang diungkapkan oleh Siswanto (2007), "Individu yang sehat dan mampu berkembang adalah individu yang bisa melihat dirinya dalam konteks ikut bertanggung jawab terhadap orang lain, terutama yang berada disekitarnya".

Salah satu cara menerapkan dan meningkatkan sikap bertanggung jawab adalah melalui pembelajaran penjas di sekolah. Pendidikan jasmani yang merupakan salah satu mata pelajaran yang diberikan di sekolah sering diartikan sebagai pembelajaran yang hanya menuntut gerak secara psikomotor saja, padahal penjas dapat dijadikan alat dalam mengembangkan kemampuan gerak, mental, emosional, bahkan pembelajaran moral. Seperti yang dikemukakan oleh Berliana dan Rismayadi (2009) "Pembinaan mental merupakan bagian dari dunia afektif, dan juga merupakan bagian penting yang harus dibina dalam dunia olahraga dan pendidikan jasmani, sehingga belief and value system" yang terkelola dan dimiliki oleh setiap dapat teraktualisasi dalam setiap aspek gerak.

Model pembelajaran yang termasuk dalam kategori rekonstruksi sosial adalah model hellison. Model hellison dikembangkan oleh Donald R. Hellison, yang dikenal dengan sebutan Teaching Responsibility Trough Physical Activity. Model Hellison atau Teaching Personal And Sosial Responsibily (TPSR) adalah model yang memperhatikan sikap, nilai-nilai dan perilaku anak didik. Sehingga sangatlah tepat untuk menerapkan model hellison ke dalam pembelajaran pendidikan jasmani di sekolah. Aktivitas fisik sangat potensial untuk mengembangkan karakter karena lingkungannya mampu mengeksplorasi emosi, suasananya interaktif, dan untuk beberapa anak sangat atraktif sehingga sangat menarik untuk dilakukan (Widiyatmoko, 2016). Dalam aktivitas fisik, siswa mempunyai kesempatan yang tidak terbatas untuk mendemostrasikan kualitas personal dan social mereka.

Jika selama ini pembelajaran aspek afektif masih belum banyak tersentuh melalui pembelajaran penjas maka sekarang sudah saatnya semua guru penjas dapat berkeinginan untuk melakukannya, dengan salah satunya adalah menerapkan model hellison sebagai pembinaan sikap bertanggung jawab melalui aktivitas jasmani. 


\section{METODE PENELITIAN}

Metode penelitian yang digunakan adalah metode eksperimen dengan desain one grup pretestposttest design. Sampel penelitian ini adalah siswa kelas XI Akuntansi yang diambil secara cluster random sampling pada siswa kelas XI di SMK TIK Yadika Cicalengka. Penelitian dilakukan 1 kali pertemuan setiap minggunya selama 8 minggu. Instrumen yang digunakan adalah angket tanggung jawab. Data yang diperoleh diolah menggunakan SPSS 24 melalui Uji-t Paired SamplesMetode yang digunakan dalam penelitian ini adalah eksperimental, dengan desain One Group Pre-test Post-test Design..

\section{HASIL DAN PEMBAHASAN}

\section{Hasil}

Uji Normalitas

Uji normalitas data dengan menggunakan pengolahan SPSS versi 24 menghasilkan tabel sebagai berikut :

Tabel 1

Uji Normalitas

\begin{tabular}{|l|l|l|l|l|l|l|}
\hline \multicolumn{1}{|c|}{ Tests of Normality } \\
\hline & \multicolumn{7}{|c|}{ Kolmogorov-Smirnov } & \multicolumn{3}{l|}{ Shapiro-Wilk } \\
\cline { 2 - 7 } & Statistic & Df & Sig. & Statistic & Df & Sig. \\
\hline Tanggungjawa & .097 & 28 & $.200^{*}$ & .942 & 28 & .126 \\
\hline
\end{tabular}

Sumber : Data Hasil Olahan SPSS 24

Analisis Shapiro-Wilk disajikan karena subjek atau kasus yang dimiliki kurang dari 50. Uji Shapiro-Wilk dianggap lebih akurat ketika jumlah subyek yang dimiliki kurang dari 50. Berdasarkan tabel di atas, kolom Sig. atau p untuk kedua uji lebih dari 0,1. Maka dapat disimpulkan bahwa data yang diuji memiliki distribusi normal.

\section{Uji Homogenitas (F)}

Uji homogenitas digunakan untuk mengetahui varian dari beberapa populasi sama atau tidak. Asumsi yang mendasari dalam Analisis of varians (ANOVA) adalah bahwa varian dari beberapa populasi adalah sama. Berikut hasil uji F: 
Tabel 2

Uji Homogenitas

\begin{tabular}{|l|l|l|l|}
\hline \multicolumn{4}{|c|}{ Test of Homogeneity of Variances } \\
\hline \multicolumn{3}{|c|}{ Posttest } \\
Levene & & & \\
Statistic & & & \\
\hline 2.988 & 4 & 10 & .073 \\
\hline
\end{tabular}

Sumber : Data Hasil Olahan SPSS 24

Berdasarkan tabel di atas, diketahui bahwa nilai Sig. sebesar 0,073 > 0,05, karena nilai Sig. sebesar 0,073 lebih besar dari 0,05 maka dapat dikatakan bahwa varian dari dua atau lebih kelompok populasi data adalah sama (homogen).

Hasil Pengujian Hipotesis

Uji paired sampel t-test digunakan untuk mengetahui apakah terdapat perbedaan rata-rata dua sampel (dua kelompok) yang berpasangan atau berhubungan. Untuk melihat apakah penerapan model hellison dalam pembelajaran penjas dapat meningkatkan sikap bertanggung jawab siswa dapat dilihat pada tabel berikut:

Tabel 3

Uji Paired Samples Statistics

\begin{tabular}{|l|l|l|l|l|l|}
\hline \multicolumn{2}{|c|}{ Paired Samples Statistics } \\
\hline & Mean & N & $\begin{array}{l}\text { Std. } \\
\text { Deviation }\end{array}$ & $\begin{array}{l}\text { Std. Error } \\
\text { Mean }\end{array}$ \\
\hline Pair 1 & Pretest & 109.32 & 22 & 12.871 & 2.744 \\
\cline { 2 - 7 } & Posttest & 117.82 & 22 & 7.829 & 1.669 \\
\hline
\end{tabular}

Pada tabel di atas, diperlihatkan hasil ringkasan statistic dari data pretest dan posttest. Untuk nilai pretest diperoleh rata-rata 109,32. Sedangkan untuk nilai posttest diperoleh nilai rata-rata 117,82 .

Tabel 4

Paired Samples Correlations

\begin{tabular}{|l|l|l|l|l|}
\hline \multicolumn{5}{|c|}{ Paired Samples Correlations } \\
\hline \multicolumn{2}{|c|}{} & N & Correlation & Sig. \\
\hline Pair 1 & Pretest \& Posttest & 22 & .888 & .000 \\
\hline
\end{tabular}

Sumber:Data Hasil Olahan SPSS 24 
Pada tabel di atas, hasil uji menunjukkan bahwa korelasi antara dua variabel adalah sebesar 0,888 dengan Sig. sebesar 0,000. Hal ini menunjukkan bahwa korelasi antara dua rata-rata hasil pretest dan posttest adalah kuat dan signifikan.

Tabel 5

Paired Samples Test

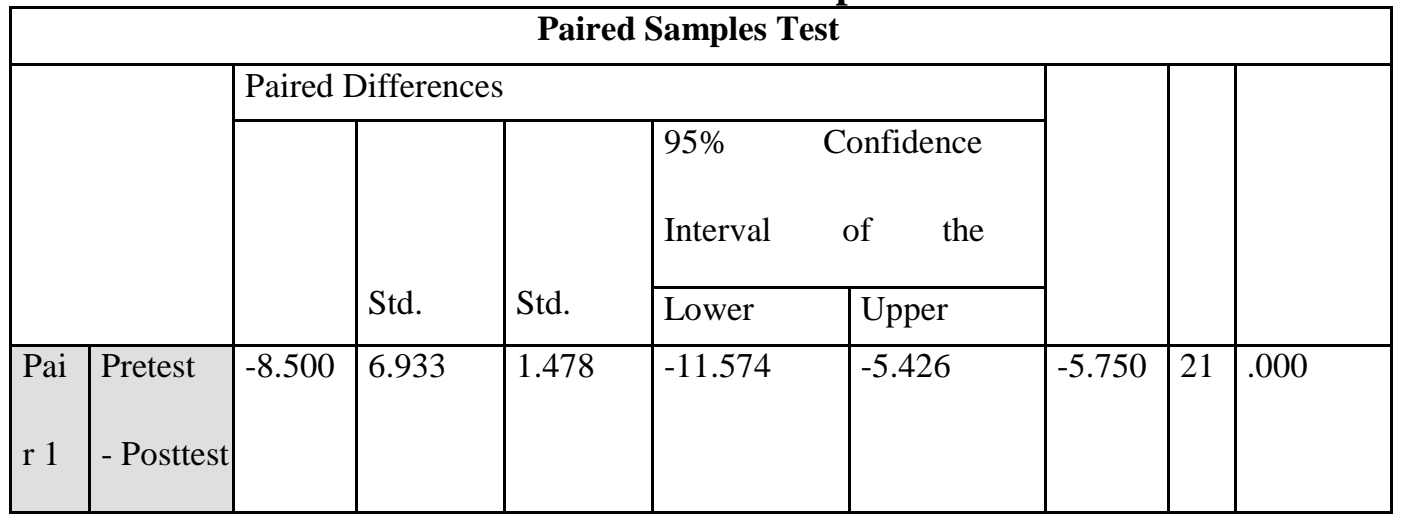

Untuk pengambilan keputusan, jika nilai probabilitas atau Sig. (2-tailed) <0,05 maka terdapat perbedaan yang signifikan antara hasil treatment pada data pretest dan posttest yang artinya terdapat pengaruh penerapan model hellison dalam pembelajaran penjas terhadap sikap tanggung jawab siswa. Sebaliknya, jika nilai probabilitas atau Sig. (2-tailed) > 0,05 maka tidak terdapat perbedaan yang signifikan antara hasil treatment pada data pretest dan posttest yang artinya tidak terdapat pengaruh penerapan model hellison dalam pembelajaran penjas terhadap sikap tanggung jawab siswa. Berdasarkan tabel di atas, diketahui bahwa nilai Sig. (2-tailed) sebesar 0,000 <0,05, karena nilai Sig. (2-tailed) sebesar 0,000 lebih kecil dari 0,05 maka dapat disimpulkan bahwa penerapan model hellison dalam pembelajaran penjas dapat meningkatkan sikap betanggung jawab siswa.

\section{Pembahasan}

Berdasarkan tabel di atas, nilai Sig. (2-tailed) sebesar 0,000<0,05, karena nilai Sig. (2tailed) sebesar 0,000 lebih kecil dari 0,05 maka dapat disimpulkan bahwa penerapan model hellison dalam pembelajaran penjas dapat meningkatkan sikap betanggung jawab siswa. Model hellison dikembangkan oleh Donald R. Hellison, yang dikenal dengan sebutan Teaching Responsibility Through Physical Activity. Hellison dalam Supriadi et al (2015), menjelaskan bahwa, "TPSR stands for a set of ideas that have grown out of my attempt to help at risk kids take more responsibility for their personal and sosial development in physical activity settings". TPSR merupakan seperangkat ide-ide yang tumbuh dari upayanya untuk meningkatkan tanggung jawab pribadi dan sosial melalui aktivitas jasmani. Model Helison ini sering digunakan untuk membina disiplin siswa (selfresponsibility) untuk itu model ini sering digunakan pada sekolah-sekolah yang bermasalah dengan disiplin siswanya. 
Dari berbagai literatur, tanggung jawab sendiri bisa diartikan sebagai perilaku seseorang untuk melaksanakan tugas dan kewajibannya yang seharusnya dilakukan terhadap diri sendiri, masyarakat, dan lingkungannya, termasuk menanggung segala konsekuensi atau akibat dari perilakunya tersebut (Samani \& Hariyanto, 2013; Tirtarahardja et al, 2010; Ulfa, 2014).

Perilaku bertanggung jawab merupakan penanaman bukan pengajaran. Pendidikan dan pembiasaan perilaku bertanggung jawab, baik di rumah, di sekolah maupun di masyarakat, bukanlah dengan mengajarkan mereka dengan teori-teori, atau apa pun namanya. Namun sebagian besar dari yang dipelajari manusia terjadi melalui peniruan (imitation) dan penyajian contoh perilaku (rolemodeling) dan pembiasaan merespons tersebut melalui pemberian penghargaan dan hukuman (Saleh, 2012).

Maka dari itu penerapan perilaku bertanggung jawab yang diintegrasikan dalam konsep pembelajaran pendidikan jasmani yang dikemas dalam bentuk model pembelajaran Hellison ini dimana siswa melakukan pembiasaan perilaku bertanggung jawab secara langsung dalam aktivitas pembelajaran gerak di dalamnya mampu meningkat (Supriadi et al, 2015; Gordon, 2011).

\section{KESIMPULAN}

Berdasarkan hasil penelitian dan pembahasan pengaruh penerapan model hellison dalam pembelajaran penjas terhadap sikap tanggung jawab siswa di SMK TIK Yadika Cicalengka melalui penyebaran angket kepada siswa maka didapat kesimpulan bahwa Pembelajaran penjas melalui penerapan model hellison memberikan pengaruh terhadap sikap bertanggung jawab siswa di SMK TIK Yadika Cicalengka. Besar pengaruh pembelajaran penjas melalui penerapan model hellison terhadap sikap bertanggung jawab siswa di SMK TIK Yadika Cicalengka adalah dengan nilai signifikansi $0,000<0,05=$ Ho ditolak. Jadi kesimpulannya adalah terdapat pengaruh yang signifikan pembelajaran penjas melalui penerapan model hellison terhadap sikap bertanggung jawab siswa di SMK TIK Yadika Cicalengka.

\section{DAFTAR PUSTAKA}

Berliana dan Alen Rismayadi. (2009). Pembelajaran Sikap Bertanggung Jawab Dan Sikap Social Melalui Pendidikan Jasmani Di Sekolah Dasar. Jurnal UPI, Volume 1, Nomor 2.

Gordon, Barrie. (2011). Teaching Personal and Social Responsibility Trough Physical Education. Journal Victoria University, 2011.

Saleh, WS. (2012). Bab II Kajian Teoretis. Online ;http://eprints.ung.ac.id/1092/6/2012-2-86201111409087-bab2-26012013035257.pdf 
Samawi, M. \& Hariyanto. (2013). Konsep dan Model Pendidikan Karakter. Bandung: PT. Remaja Rosdakarya.

Siswanto(2007). Kesehatan Mental: Konsep, Cakupan dan Perkembangannya. Yogyakarta: CV. Andi Offset

Sukardjo dan Komarudin (2009). Landasan Pendidikan Konsep \& Aplikasinya. Jakarta: PT Raja Grafindo

Supriadi, Dedi., et al. (2015). Implementasi Model Pembelajaran Teaching Personal and Social Responsibility (TPSR) untuk Peningkatan Sikap Tanggungjawab Mahasiswa STKIP Pasundan Cimahi. Jurnal STKIP Pasundan Cimahi

Tirtarahardja, Umar \& La Sulo. (2010). Pengantar Pendidikan Edisi Revisi. Jakarta: PT Asdi Mahasatya

Ulfa, D. (2014). Meningkatkan Tanggung Jawab Belajar dengan Layanan Konseling Individual Self Management. Skripsi UNNES

Widiyatmoko, Fajar Ari (2016). "Meningkatkan Sikap Tanggung Jawab Mahasiswa Melalui Pembelajaran Bola Basket”. Jurnal Universitas PGRI Semarang, Volume 1-1 